\title{
IDENTIFIKASI JENIS ANGGREK (Orcidaceae) DI KEBUN RAYA LEMOR DESA SUELA KECAMATAN SUELA KABUPATEN LOMBOK TIMUR
}

Oleh:

\author{
Moh. Januar Rinaldi, Raden Roro Narwastu Dwi Rita \\ Program Studi Kehutanan Universitas Pendidikan Mandalika
}

\begin{abstract}
Abstrak
Adapun tujuan penelitian ini adalah 1. Mengetahui jenis-jenis anggrek endemik lombok dan yang bukan endemik yang terdapat di blok koleksi taman anggrek kebun raya lemor Desa suela Kecamatan suela. Kabupaten Lombok Timur.2, Untuk Mengetahui jenis Anggrek berdasarkan Habitatnya yang ada di kebun raya lemor 3. Mengetahui jenis-jenis tumbuhan yang menjadi penopang setiap jenis anggrek yang terdapat di blok koleksi taman anggrek kebun raya lemor.Desa suela Kecamatan suela.KabupatenLombok Timur. . Metodologi Penelitian Penelitian yang dilakukan yakni penelitian dengan pendekatan kualitatif dan bersifat deskriptif, Terdapat 2 jenis Anggrek yang merupakan endemik Lombok yaitu vanda lombokensis dan Dendrobium rinjaniense. Sedangkan yang teridentifikasi hanya vanda lombokensis.ciri khas bunga anggrek endemik lombok ini terdapat pada warna dasar kelopak bunga, yakni putih dan kuning serta totolnya yang khas dengan warna cokelat dan merah..dan terdapat pula anggrek bukan endemik Lombok yang teridentifikasi sebanyak 58 jenis. Jenis Anggrek berdasarkan Habitatnya di temukan yaitu epipit, terrestrial jumlah jenis epipit sendiri sebanyak 38 jenis dan jumlah terrestrial 22 jenis. Dan di temukan ada 6 penopang untuk anngrek yaitu Mangga,jambu batu,rambutan,jabon ,kamboja,jeruk.
\end{abstract}

Kata Kunci: Anggrek, Kebun Raya Lemor

\section{PENDAHULUAN}

Setiap bentuk Ekosistem hutan mempunyai kemampuan yang berbeda dalam hal pemenuhan kebutuhannya akan kondisi lingkungan termasuk unsur-unsur iklim. Adanya perbedaan dalam pemenuhan kebutuhan hidup tersebut dapat membentuk masyarakat tumbuhan yang mempunyai cirri khas tertentu,termasuk tumbuhan pohon, semak belukar,pemanjat, pencekik, parasit, dan epifit.Anggrek merupakan family terbesar yang menempati 7-10\% tumbuhan berbunga yang ada di Dunia Anggrek yang ada di Indonesia diperkirakan terdapat 4.000-5.000 jenis (Latief,1960).Indonesia merupakan Negara yang menyimpan kekayaan plasma nutfah anggrek paling besar di Dunia.Dari sekitar 26.000 spesies, Indonesia memiliki sekitar 6.000 spesies tanaman anggrek dunia.Indonesia merupakan Negara tropis dan memiliki kondisi lingkungan yang memenuhi syarat untuk menjamin kehidupan tanaman anggrek.Anggrek spesies atau anggrek alam adalah anggrek yang dapat ditemukan di alam dan sama sekali belum disilangkan dengan tanaman anggrek lainnya, anggrek alam ini dapat ditemukan di kawasan hutan, topografi ataupun vegetasi-vegetasi lain. Meskipun masih berupa anggrek yang belum disilangkan anggrek alam masih memiliki bentuk dan warna yang indah serta menarik (Kartohadiprodjo, 2009).

Tanaman anggrek di Indonesia diperkirakan ada sekitar 5.000 jenis (Heriswanto, 2009).Karena anggrek memiliki nilai jual tinggi sehingga kolektor dan pembisnis berniat untuk mengoleksi anggrek sebagai tanaman hias, dikarenakan bunga anggrek memiliki bentuk bunga yang sangat beragam dan memiliki daya tarik untuk dikoleksi.Sehingga banyak kolektor dan pembisnis membuat penangkaran anggrek karena penangkaran juga termasuk dalam konservasi ek-situ dimana konservasi ek-situ mempunyai fungsi utama yaitu sebagai fungsi ekologi serta fungsi social ekonomi dan social budaya.KebunRaya Lemor (KRL) merupakan salah satu kebun raya daerah yang terletak di Desa Suela, Kecamatan Suela, Kabupaten Lombok Timur Provinsi NTB

Bebrapa jenis tumbuhan yang terdapat di Kebun Raya Lemor, antara lain ,koleksi yang sudah tertanam sebanyak 1.979 spesimen,284 jenis, 270 marga, 178 masihsp, serta 35 suku.beberapa koleksi yang dimiliki ini data 
dalam bentuk taman tematik seperti taman buah lokal dan taman anggrek. Sedangkan koleksi yang sudah tertanam sebanyak 1.979 spesimen,284 jenis, 270 marga,178 masihspserta 35 suku (Anonymous, 2019)

Tujuan penelitian ini dalah untuk mengetahui jenis-jenis anggrek endemik lombok dan yang bukan endemik yang terdapat di blok koleksi taman anggrek kebun raya lemor Desa suela Kecamatan suela. Kabupaten Lombok Timur. Untuk Mengetahui jenis Anggrek berdasarkan Habitatnya yang ada di kebun raya lemor. Mengetahui jenis-jenis tumbuhan yang menjadi penopang setiap jenis anggrek yang terdapat di blok koleksi taman anggrek kebun raya lemor.Desa suela Kecamatan suela.KabupatenLombok Timur.

\section{METODOLOGI PENELITIAN}

Penelitian yang dilakukan yakni penelitian dengan pendekatan kualitatif dan bersifat deskriptif. Kehadiran peneliti berperan dalam pengambilan data dan instrumen atau alat dalam pengambilan data tersebut. Data yang diperoleh adalah jenis data deskriptif kualitatif yang diperoleh dari lapangan atau tempat penelitian. Sumber data yang diperoleh dari beberapa kriteria yang dikumpulkan meliputi, nama anggrek baik Indonesia (nama daerah)atau pun Latin, jenis anggrek, habitat anggrek, tanaman inang (jika anggrek epifit), jumlah anggrek, serta keterangan dan manfaat anggrek.

\section{a. Alat dan Bahan}

Alat yang digunakan dalam penelitian ini adalah Tally sheet, Meteran roll, Alat tulis menulis dan Kamera untuk mengambil gambar

\section{b. Rancangan Percobaan}

Jika penelitian bersifat eksperimental, sebutkan rancangan percobaan yang digunakan. Jika penelitian non - eksperimental disebutkan parameter penelitian, batasan penelitian serta data - data apa saja yang akan dikumpulkan

\section{c. Cara Kerja}

Data yang dikumpulkan dalam penelitian ini meliputi :Jenis-jenis anggrek dan golongan habitatnya, Jenis-jenis tumbuhan sebagai penopang (tempat hidup) anggrek.

Ruang lingkup dan batasan dalam penelitian ini adalah.lokasi penelitian di lakukan di Blok Koleksi taman anggrek kebun raya lemor
Anggrek yang diamati meliputi golongan epifit, terestrial, lithofit, dan saprofit dengan alasan belum adanya data seluruhanggrek di blok koleksi tumbuhan dan satwa sehingga diperlukan penelitian ini untuk menjadi acuan pengembangan blok tersebut dan untuk penelitian selanjutnya.

\section{d. Analsis Data}

Pendataan identifikasi menggunakan buku katalok anggrek, kemudian data ditabulasi dan di deskripsikan

\section{HASIL dan PEMBAHASAN}

\section{A. Hasil}

\section{kondisi umum lokasi penelitian \\ 1. letak luas penelitian}

Secara geografis wilayah Desa Suela KecamatanSuela Kabupaten Lombok Timur terletak di utara wilayah Kecamatan Suela dengan batas-batas wilayah :Sebelah Utara :: Kecamatan Sembalun. Sebelah Selatan Kecamatan Wanasaba, Sebelah Barat Kecamatan Pringgabaya, Sebelah Timur : Kecamatan Pringgabaya

Luas wilayah Kecamatan Suela adalah seluas $115,01 \mathrm{~km} 2$ dan terdiri dari 8 desa, Tinggi kecamatan suela dari permukaan air laut 400 meter sedangkan untuk desa suela sendiri mempunyai luas wilayah $9,94 \mathrm{~km} 2$.

\section{2. sejarah dan kondisi kebun raya}

Kebun Raya adalah kawasan konservasi tumbuhan secara eks-situ yang memiliki koleksi tumbuhan terdokumentasi dan di tata berdasarkan pola klasifikasi taksonomi ,bioregion,tematik, atau kombinasi dari polapola tersebut untuk tujuan kegiatan konservasi,penelitian, pendidikan, wisata dan jasa lingkungan. Pada tahun 2017 Tim pusat Konservasi tumbuhan (LIPI) melakukan survei lokasi calon kebun raya di NTT dan NTB. Kebun raya ini mengusung tema konservasi kepulauan sunda kecil(pulau lombok, komodo,rinca,sumbawa,flores dan sumba sampai Timor barat dari hasil analisis kelayakan Hutan Lindung Lemor (Hutan lindung Petandakan) yang berada di Desa Suela Kabupaten Lombok Timur,Nusa Tenggara Barat terpilih menjadi lokasi pembangunan kebun raya yang selanjutnya diberi nama kebun raya lombok. Selanjutnya,kawasan Hutan Lindung Petandakan yang berfungsi Lindung di tetapkan sebagai Kawasan Hutan dengan tujuan khusus (KHDTK) melalui keputusan menteri kehutanan 
Nomor. SK.22/menhut-II/2012 Kebun Raya lombok terdiri dari areal hutan (untuk areal konservasi in situ ) seluas 82,9ha dan areal terbuka/kopang II Seluas 48ha (untuk areal konservasi eks-situ) kebun raya lombok mempunyai koleksi tumbuhan tertanam sebanyak 1,227 spesimen tumbuhan,Anggrek: 30 genus ,42 species dan 90 masih sp, non anggrek : 31 famili, 126 genus ,115 spesies , 121 masih sp.

\section{Tanah}

jenis tanah di wilayah Desa tersebut yaitu sebagian besar warna tanahnya merah. Hal ini terjadi karena tanah ini terbentuk dalam proses yang panjang dan bercampur dengan berbagai jenis tanah lainnya dan mengendap jadi satu. Tekstur tanahnya lempungan. Tanah ini umumnya keras ketika kering. Namun ketika terkena air akan lengket. Hal ini terjadi karena kandungan jenis mineral lempung yang banyak terkandung dalam tanah.(Sumber : proyeksi BPS kab.Lombok Timur)

\section{Topografi}

Wilayah Desa Suela merupakan daerah yang berbukit-bukit dengan kemiringan tanah yang bervariasi antara $2^{0}-15^{0}$ derajat, berbukit dan lembah diwilayah ini ditumbuhi berbagai jenis tanaman dengan kondisi hutan yang masih alami sehingga mencipta bentuk bentang lahan yang indah dan menarik.

\section{Iklim dan Curah Hujan}

Secara umum iklim wilayah Desa suela tergolong dalam iklim tropis, berdasarkan Schmidt dan Ferguson termasuk dalam iklim tropis type $\mathrm{B}$ dengan temperatur rata-rata berkisar antara $20,9-32,9^{\circ} \mathrm{C}$. Musim hujan biasanya berlangsung antara 6 bulan, intensitas curah hujan berkisar antara 2.000-3.000 Mm, curah hujan terrendah terjadi pada bulan November dan curah hujan tertinggi pada bulan Februari.

\section{Topografi dan Demografi Desa}

Desa Suela terletak di daerah pegunungan dengan :
a. Topografi
Dataran Tinggi
b. Suhu Udara
$20,9^{\circ} \mathrm{C}-32,9^{\circ} \mathrm{C}$
c. Jumlah Dusun :
4 dusun
d. Jumlah Puskesmas :1 unit

\section{Jumlah penduduk Desa Suela}

Tabel 1. Jumlah Penduduk

\begin{tabular}{ccc}
\hline NO & PENDUDUK & JUMLAH \\
\hline 1 & Laki - Laki & 2.889Jiwa \\
\hline 2 & Perempuan & 3.384Jiwa \\
\hline & Total & 6.273Jiwa \\
\hline
\end{tabular}

Sumber : proyeksi BPS kab.Lombok Timur

Dari tabel diatas jumlah penduduk Desa Suela berjumlah 6.273 jiwa dari jumlah penduduk laki - laki 2.889 jiwa dan jumlah penduduk perempuan berjumlah 3.384 jiwa.

\section{Kebersihan Lingkungan Dan Kesehatan Masyarakat}

Penduduk Desa Suela memperoleh air minum, mencuci dan mandiberasal dari sumber mata air yang dialirkan dengan menggunakan saluranperpipaan yang berasal dari pegunungngan, sehingga air tersebut dapatlangsung dialirkan kesetiap rumah penduduk. Selain itu juga terdapat aliran airsungai dan sumur galian.

\section{Jenis Anggrek endemik lombok}

Tabel 2. Jenis Anggrek endemic Lombok

\begin{tabular}{lll}
\hline NO & NAMA & ASAL \\
\hline 1 & $\begin{array}{l}\text { Vanda Lombokensis JJ. } \\
\text { Sm }\end{array}$ & Sunda Kecil NTT \\
\hline 2. & $\begin{array}{l}\text { Dendrobium rinjaniensi } \\
\text { (Anggrek Tasbih) }\end{array}$ & Gunung Rinjani \\
\hline
\end{tabular}

10. Jenis Anggrek Berdasarkan Habitat Epipit yang ada di kebun Raya Lemor Desa Suela Kecamatan Suela

\begin{tabular}{|c|c|c|c|}
\hline $\mathrm{NO}$ & Nama Amggrek & Genus & Sumber \\
\hline 1 & $\begin{array}{l}\text { Bulbophyllumlobbii } \\
\text { Lindl. }\end{array}$ & $\begin{array}{l}\text { Bulbophyllu } \\
\text { mlobbii }\end{array}$ & $\begin{array}{l}\text { H.L Sebau, Ds. Sapit } \\
\text { Kec. Suela } \\
\text { Kab.Lombok Timur }\end{array}$ \\
\hline 2 & $\begin{array}{l}\text { Polydota imbricate } \\
\text { Lindl }\end{array}$ & Polydota & $\begin{array}{l}\text { HL. Sesaot Kec. } \\
\text { Narmada- Lombok } \\
\text { Barat }\end{array}$ \\
\hline 3 & $\begin{array}{l}\text { Coelogyne speciosa } \\
\text { (Blume) Lindl. }\end{array}$ & Coelogyne & TNGR Sembalun \\
\hline 3 & $\begin{array}{l}\text { Thrixspermum } \\
\text { centipeda Lour }\end{array}$ & $\begin{array}{l}\text { Thrixspermu } \\
m\end{array}$ & H.L Lemor \\
\hline 5 & $\begin{array}{l}\text { Dendrochilum } \\
\text { pallidiflavens Blume }\end{array}$ & $\begin{array}{l}\text { Dendrobhilu } \\
m\end{array}$ & H.L Sesaot \\
\hline 6 & Bulbophyllum sp. & $\begin{array}{l}\text { Bulbophyllu } \\
m\end{array}$ & $\begin{array}{l}\text { HL. Sesaot Kec. } \\
\text { Narmada- Lombok } \\
\text { Barat }\end{array}$ \\
\hline 7 & $\begin{array}{l}\text { Dendrobium } \\
\text { crumenatum Swartz. }\end{array}$ & Dendrobium & $\begin{array}{l}\text { HL.Sesaot Kec. } \\
\text { Narmada- Lombok } \\
\text { Barat }\end{array}$ \\
\hline 8 & $\begin{array}{l}\text { Appendicularamosa } \\
\text { Blume }\end{array}$ & $\begin{array}{l}\text { Appendicula } \\
\text { ramosa }\end{array}$ & $\begin{array}{l}\text { Taman Nasional } \\
\text { Gunung Rinjani }\end{array}$ \\
\hline 9 & $\begin{array}{l}\text { Eriaverruculosa } \\
\text { J.J.Sm. }\end{array}$ & Eria & $\begin{array}{l}\text { Taman Nasional } \\
\text { Gunung Rinjani }\end{array}$ \\
\hline 10 & Tuberolabium sp. & $\begin{array}{l}\text { Tuberolabiu } \\
m\end{array}$ & $\begin{array}{l}\text { Taman Nasional } \\
\text { Gunung Rinjani }\end{array}$ \\
\hline 11 & Acampe sp. & Vanda & $\begin{array}{l}\text { Taman Nasional } \\
\text { Gunung Rinjani }\end{array}$ \\
\hline 12 & Vanda limbata & Vanda & $\begin{array}{l}\text { Taman Nasional } \\
\text { Gunung Rinjani }\end{array}$ \\
\hline
\end{tabular}




\begin{tabular}{|c|c|c|c|}
\hline 13 & Coelogyne sp. & Coelogyne & Hutan Lindung Sebau \\
\hline 14 & $\begin{array}{l}\text { Bulbophyllum } \\
\text { biflorum Teijsm. \& } \\
\text { Binn. }\end{array}$ & $\begin{array}{l}\text { Bulbophyllu } \\
m\end{array}$ & $\begin{array}{l}\text { HL Lemor, Lombok } \\
\text { Timur }\end{array}$ \\
\hline$\overline{15}$ & Bulbophyllum sp. & $\begin{array}{l}\text { Bulbophyllu } \\
m\end{array}$ & $\begin{array}{l}\text { HL Lemor, Lombok } \\
\text { Timur }\end{array}$ \\
\hline$\overline{16}$ & $\begin{array}{l}\text { Coelogyne speciosa } \\
\text { (Blume) Lindl. }\end{array}$ & Coelogyne & $\begin{array}{l}\text { HL Sembalun, } \\
\text { Sembalun Bumbung, } \\
\text { Lombok Timur }\end{array}$ \\
\hline 17 & Liparis sp. & Liparis & $\begin{array}{l}\text { HL Sembalun, } \\
\text { Sembalun Bumbung, } \\
\text { Lombok Timur }\end{array}$ \\
\hline 18 & $\begin{array}{l}\text { Calathe triplicata } \\
\text { (Willemet) Ames }\end{array}$ & $\begin{array}{l}\text { Calathe } \\
\text { triplicata }\end{array}$ & $\begin{array}{l}\text { HL Pusuk, Sembalun, } \\
\text { Lombok Timur }\end{array}$ \\
\hline 19 & $\begin{array}{l}\text { Thelasis carinata } \\
\text { Blume }\end{array}$ & Vanda & $\begin{array}{l}\text { HL Pusuk, Sembalun, } \\
\text { Lombok Timur }\end{array}$ \\
\hline 20 & Pteroceras sp. & Pteroceras & $\begin{array}{l}\text { HL Pusuk, Sembalun, } \\
\text { Lombok Timur }\end{array}$ \\
\hline 21 & Eria sp. & Eria & $\begin{array}{l}\text { Hutan Sakdah, } \\
\text { Pesugulan, Lombok } \\
\text { Timur }\end{array}$ \\
\hline 22 & $\begin{array}{l}\text { Lipariscompressa } \\
\text { (Blume) }\end{array}$ & Liparis & $\begin{array}{l}\text { Hutan Sakdah, } \\
\text { Pesugulan, Lombok } \\
\text { Timur }\end{array}$ \\
\hline 23 & Eria xanthocheila & Eria & $\begin{array}{l}\text { Hutan Sakdah, } \\
\text { Pesugulan, Lombok } \\
\text { Timur }\end{array}$ \\
\hline 24 & $\begin{array}{l}\text { Eria verruculosa } \\
\text { J,J.Sm. }\end{array}$ & Eria & $\begin{array}{l}\text { Hutan Sakdah, } \\
\text { Pesugulan, Lombok } \\
\text { Timur }\end{array}$ \\
\hline 25 & $\begin{array}{l}\text { Ceratostylis } \\
\text { crassifolia J.J.Sm. }\end{array}$ & Ceratostylis & $\begin{array}{l}\text { Hutan Sakdah, } \\
\text { Pesugulan, Lombok } \\
\text { Timur }\end{array}$ \\
\hline 26 & $\begin{array}{l}\text { Polystachya concreta } \\
\text { (Jacq.) Garay \& H.R } \\
\text { Sweet }\end{array}$ & Polystachya & $\begin{array}{l}\text { Sembalun, Lombok } \\
\text { Timur }\end{array}$ \\
\hline 27 & Vanda limbata Blume & Vanda & $\begin{array}{l}\text { HL Sembalun, Lombok } \\
\text { Timur }\end{array}$ \\
\hline 28 & $\begin{array}{l}\text { Vanda lombokensis } \\
\text { J.J. Sm. }\end{array}$ & Vanda & $\begin{array}{l}\text { HL Sembalun, Lombok } \\
\text { Timur }\end{array}$ \\
\hline 29 & $\begin{array}{l}\text { Eria javanica }(S w .) \\
\text { Blume }\end{array}$ & $\begin{array}{l}\text { Eria } \\
\text { javanica }\end{array}$ & $\begin{array}{l}\text { HL Sembalun, Lombok } \\
\text { Timur }\end{array}$ \\
\hline 30 & Aerides odorata Lour & Odorata & $\begin{array}{l}\text { HL Sembalun, Lombok } \\
\text { Timur }\end{array}$ \\
\hline 31 & Tuberolabium $s p$. & $\begin{array}{l}\text { Tuberolabiu } \\
m\end{array}$ & $\begin{array}{l}\text { HL Sembalun, Lombok } \\
\text { Timur }\end{array}$ \\
\hline 32 & Acampe sp. & Acampe & $\begin{array}{l}\text { HL Sembalun, Lombok } \\
\text { Timur }\end{array}$ \\
\hline 33 & $\begin{array}{l}\text { Pholidota imbricata } \\
\text { Lindl. }\end{array}$ & $\begin{array}{l}\text { Pholidota } \\
\text { imbricata }\end{array}$ & $\begin{array}{l}\text { HL Sembalun, Lombok } \\
\text { Timur }\end{array}$ \\
\hline 34 & $\begin{array}{l}\text { Appendicula } \\
\text { infundibuliformis } \\
\text { J.J.Sm. }\end{array}$ & Appendicula & $\begin{array}{l}\text { HL Sembalun, Lombok } \\
\text { Timur }\end{array}$ \\
\hline 35 & $\begin{array}{l}\text { Dendrobium } \\
\text { crumenatum Swartz. }\end{array}$ & Dendrobium & $\begin{array}{l}\text { HL Sembalun, Lombok } \\
\text { Timur }\end{array}$ \\
\hline 36 & Liparis $s p$. & Liparis & $\begin{array}{l}\text { HL Sembalun, Lombok } \\
\text { Timur }\end{array}$ \\
\hline 37 & $\begin{array}{l}\text { Calathe triplicata } \\
\text { (Willemet) Ames }\end{array}$ & $\begin{array}{l}\text { Calathe } \\
\text { triplicata }\end{array}$ & $\begin{array}{l}\text { HL Sembalun, Lombok } \\
\text { Timur }\end{array}$ \\
\hline 38 & $\begin{array}{l}\text { Thelasis carinata } \\
\text { Blume }\end{array}$ & Thelasis & $\begin{array}{l}\text { HL Sembalun, Lombok } \\
\text { Timur }\end{array}$ \\
\hline
\end{tabular}

\section{b. jenis anggrek Berdasarkan Habitat terrestrial yang ada di kebun Raya Lemor Desa Suela Kecamatan Suela}

No Nama Anggrek Genus Sumber

\begin{tabular}{|c|c|c|c|}
\hline 1 & $\begin{array}{l}\text { Eulophia } \\
\text { spectabilis } \\
\text { (Dennst.) Suresh }\end{array}$ & Eulophia & $\begin{array}{l}\text { Kec. Sembalun, Desa } \\
\text { Sembalun }\end{array}$ \\
\hline 2 & $\begin{array}{l}\text { Coelogyne } \\
\text { speciosa }\end{array}$ & Coelogyne & $\begin{array}{l}\text { HL Pusuk, Sembalun, } \\
\text { Lombok Timur }\end{array}$ \\
\hline 3 & & Malaxis & Sembalun, TNGR \\
\hline & Malaxis sp. & & \\
\hline 4 & $\begin{array}{l}\text { Nervilia concolor } \\
\text { (Blume) Schltr. }\end{array}$ & Nervilia & HL Sebau, Lombok Timur \\
\hline$\overline{5}$ & $\begin{array}{l}\text { Paphiopedillum } \\
\text { sp. }\end{array}$ & $\begin{array}{l}\text { Paphiopedi } \\
\text { llum }\end{array}$ & HL Sebau, Lombok Timur \\
\hline 6 & $\begin{array}{l}\text { Goodyera } \\
\text { reticulata (Blume) } \\
\text { Blume }\end{array}$ & $\begin{array}{l}\text { Goodyera } \\
\text { reticulata }\end{array}$ & $\begin{array}{l}\text { HL Pusuk, Sembalun, } \\
\text { Lombok Timur }\end{array}$ \\
\hline 7 & $\begin{array}{l}\text { Goodyera } \\
\text { procera. }(\text { Ker- } \\
\text { Gawl) Hook } \\
\end{array}$ & Goodyera & $\begin{array}{l}\text { HL Pusuk, Sembalun, } \\
\text { Lombok Timur }\end{array}$ \\
\hline 8 & $\begin{array}{l}\text { Calathetriplicata( } \\
\text { Willemet) Ames }\end{array}$ & $\begin{array}{l}\text { Calathetrip } \\
\text { licata }\end{array}$ & $\begin{array}{l}\text { HL Pusuk, Sembalun, } \\
\text { Lombok Timur }\end{array}$ \\
\hline 9 & $\begin{array}{l}\text { Arundinagraminif } \\
\text { olia(D.Don) } \\
\text { Hochr. }\end{array}$ & $\begin{array}{l}\text { Arundinagr } \\
\text { aminifolia }\end{array}$ & Dasan Erot, Kec. Wanasaba \\
\hline 10 & $\begin{array}{l}\text { Calanthe } \\
\text { triplicata } \\
\text { (Willemet) Ames }\end{array}$ & Calanthe & $\begin{array}{l}\text { H.L Lemor, Ds.Suela, } \\
\text { kec.Suela, kab.Lombok } \\
\text { Timur }\end{array}$ \\
\hline 11 & $\begin{array}{l}\text { Goodyera procera } \\
\text { (Ker Gawl.) } \\
\text { Hook. }\end{array}$ & Goodyera & $\begin{array}{l}\text { H.L Lemor, Ds.Suela, } \\
\text { kec.Suela, kab.Lombok } \\
\text { Timur }\end{array}$ \\
\hline 12 & $\begin{array}{l}\text { Calanthesylvatica } \\
\text { (Thouars) Lindl. }\end{array}$ & Calanthes & $\begin{array}{l}\text { H.L Lemor, Ds.Suela, } \\
\text { kec.Suela, kab.Lombok } \\
\text { Timur }\end{array}$ \\
\hline 13 & $\begin{array}{l}\text { Corymborkis } \\
\text { veratrifolia } \\
\text { (Reinw.) Blume }\end{array}$ & $\begin{array}{l}\text { Corymbork } \\
\text { is }\end{array}$ & HL Sebau, Lombok Timur \\
\hline 14 & $\begin{array}{l}\text { Tropidia angulosa } \\
\text { (Lindl.) Blume }\end{array}$ & Tropidia & HL Sebau, Lombok Timur \\
\hline 15 & $\begin{array}{l}\text { Phaius } \\
\text { tankervilleae } \\
\text { (Banks) Blume } \\
\end{array}$ & Phaius & HL Sebau, Lombok Timur \\
\hline$\overline{16}$ & Spathoglottis sp. & $\begin{array}{l}\text { Spathoglott } \\
\text { is }\end{array}$ & HL Sebau, Lombok Timur \\
\hline 17 & Phaius sp. & Phaius & HL Sebau, Lombok Timur \\
\hline 18 & Malaxis sp. & Malaxis & HL Sebau, Lombok Timur \\
\hline 19 & $\begin{array}{l}\text { Crepidium } \\
\text { koordersii } \\
\text { (J.J.Sm.) Szlach }\end{array}$ & Crepidium & HL Sebau, Lombok Timur \\
\hline 20 & Plocoglottis sp. & $\begin{array}{l}\text { Plocoglotti } \\
S\end{array}$ & TNG. Rinjani \\
\hline 21 & $\begin{array}{l}\text { Corymborkis } \\
\text { veratrifolia } \\
\text { (reinw) Blume } \\
\end{array}$ & $\begin{array}{l}\text { Corymbork } \\
\text { is }\end{array}$ & $\begin{array}{l}\text { H.L Lemor, Ds.Suela, } \\
\text { kec.Suela, kab.Lombok } \\
\text { Timur }\end{array}$ \\
\hline 22 & Spathoglootis $s p$ & $\begin{array}{l}\text { Spathogloo } \\
\text { tis }\end{array}$ & $\begin{array}{l}\text { H.L Lemor, Ds.Suela, } \\
\text { kec.Suela,kab.Lombok } \\
\text { Timur }\end{array}$ \\
\hline
\end{tabular}

Sumber : Data Koleksi Anggrek Kebun Raya Lemor 
11. Berdasarkan Jenis pohon penopang Anggrek yang ada di kebun raya lemor Desa Suela Kecamatan Suela

\begin{tabular}{ccc}
\hline No & Pohon penopang & Nama Latin \\
\hline 1. & Mangga & Mangifera \\
\hline 2. & Kamboja & $\begin{array}{c}\text { Plumeria Rubra L.Cv } \\
\text { Acutifolia }\end{array}$ \\
\hline 3. & Rambutan & $\begin{array}{c}\text { Nephelium } \\
\text { Lappaceum }\end{array}$ \\
\hline 4. & Jambu batu & Psidium Guajava \\
\hline 5. & Jabon & Neolamarckia \\
& & Cadamba \\
\hline 6. & Jeruk & Citrus \\
\hline
\end{tabular}

\section{B. Pembahasan}

Jenis Anggrek yang berasal dari Lombok endemik dan bukan endemik

\section{Vanda lombokensis}

Ciri utama vanda lombokensis terletak pada totolnya yang kuat dibandingkan dengan anggrek tricolor, totol anggrek vanda lombokensis lebih padat dan pekat menurut para kolektor dan tim Kebun Raya Lemor, anggrek vanda lombokensis mulai di telusuri keberadaannya di wilayah TNGR Lombok sekitar 7 tahun yang lalu .menurut para kolektor ,berdasarkan corak bunganya ,anggrek vanda lombokensis terdiri atas sebelas 11 varian.Namun,yang teridentifikasi dalam Penelitian ini baru 6

Anggrek ini adalah anggrek asli Indonesia yan ditemukan oleh Johannes Jacobus Sm di kepulauan Sunda Kecil (Nusa Tenggara Barat) ( Anonymous, 2019)

memiliki varian-varian yang unik dengan ciri yang disebutnya sebagai putih totol cokelat, kuning totol cokelat, dan putih kekuningan totol cokelat.

$\begin{array}{ll}\text { Nama tanaman } & \text { :vanda lombokensis } \\ \text { family } & \text { :orchidaceae } \\ \text { Habitus } & \text { : Epipit } \\ \text { Pohon penopang } & \text { : jambu batu } \\ \text { Sumber } & \text { : TNGR }\end{array}$
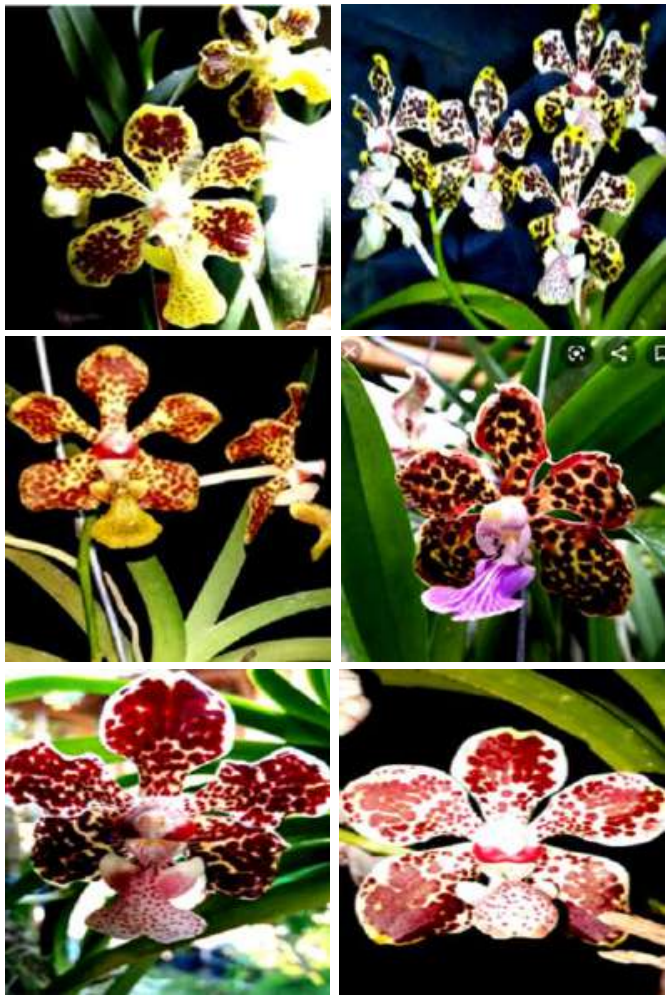

Gambar 1. Berbagai variasi Vanda lombokensis

\section{Anggrek Dendrobium rinjandjaniense}

Anggrek Dendrobium rindjaniense adalah anggrek spesies endemic Rinjani yang diketemukan pada ketinggian 1025-2000 mdpl, anggrek ini lebih dikenal dengan nama anggrek tasbih karena keunikan bagian batanggya yang menyerupai tasbih Anonymous

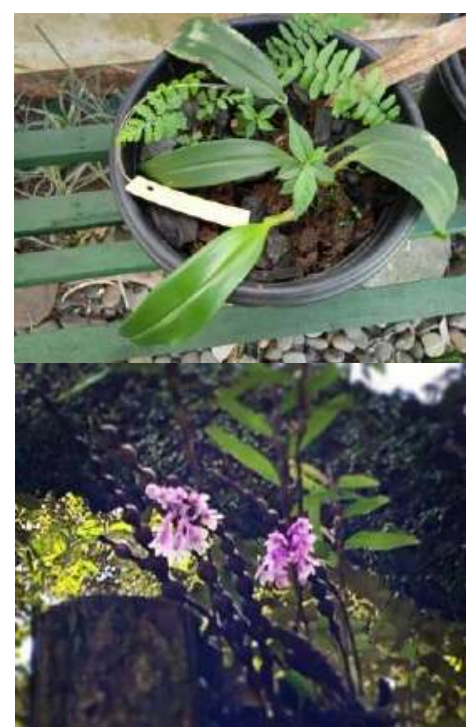

Gambar 2. Variasi Dendrobium rinjandjaniense

Jenis anggrek bukan endemik lombok 1.Corymborkis veratrifolia 


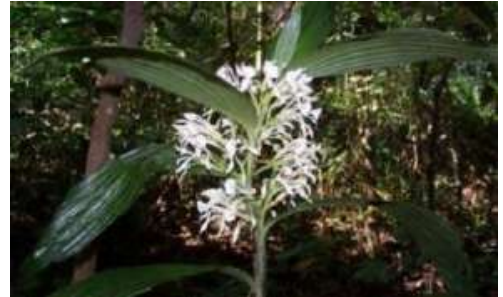

Gambar.3 Corymborkis veratrifolia

Nama lokal : Anggrek kayu manis putih Family

Habitus

Sumber orchidaceae

:Terestrial

:HL Sesaot

Anggrek kayu manis putih adalah tanaman dalam keluarga anggrek dan merupakan, tanaman asli daerah trofis anngrek terestrial ini dengan ciri batang tipis ,tegak, daun berlipit,dan batang berbunga pendek dengan enam puluh bunga hijau dan putih berumur pendek yang penuh sesak.

\section{Spathoglottis}

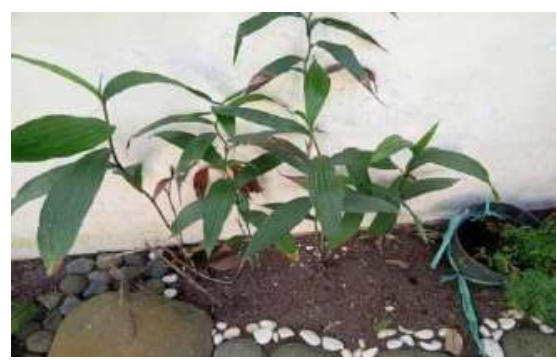

Gambar.4 Spathoglottis

Nama lokal : Anggrek tanah(ground orchid) Family

Habitus orchidaceae

Sumber

:Terestrial

:HL lemor

Anggrek tanah merupakan anggrek yang bisa tumbuh ditanah dengan pola pertumbuhan sympodial(kesamping) dengan tempratur $28^{\circ}, \pm$ $32^{\circ} \mathrm{C}$ sampai dengan tempratur minimum $15^{\circ} \mathrm{C}$. Bunga tanaman ini memiliki bunga yang berwarna warni cantik sedangkan batang tegak, bulat, lunak, berbulu, batang di dalam tanah membentuk umbi hijau.Daun berwarna hijau muda kaku dan berlekuk seperti diwiru. Tunggal , lonjong berseling panjang $5-8 \mathrm{~cm}$ lebar $0,5-1 \mathrm{~cm}$ tepi,rata,ujung runcing,pangkal tumpul, pertulangan menyirip hijau di daerah tertentu di indonesia daunnya biasa di manfaatkan sebagai pembungkus panganan khas daerah.

\section{Bulbophyllum lobbii}

Nama lokal : Anggrek lidah bergoyang

Family : orchidaceae

Habitus

: epifit

Sumber

: HL sebau

Media tanam :rumput rumputan,serabut kelapa,pot

Tanaman anggrek ini berukuran kecil hingga sedang anngrek Bulbophyllum lobii ini hidup pada cabang pepohonan di dataran rendah hingga tinggi anggrek ini tumbuh bagus di cuaca panas hingga sedang sesuai dengan sebutannya anggrek ini memiliki keunikan yaitu lidah bergoyang dan dari bunga anggrek ini dapat bergoyang ketika di sentuh atau tertiup angin dari keunikan ini juga anggrek ini di buru banyak para kolektor, sehingga keberadaannya jarang di temui dalam usia dewasa.

\section{Trichoglatis $s p$}

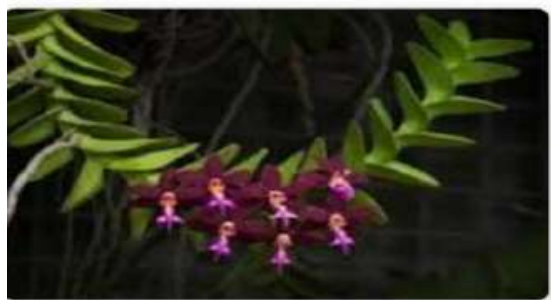

Gambar5. Trichoglatis sp

$\begin{array}{ll}\text { Nama lokal } & \text { : Anggrek kerub } \\ \text { Family } & \text { :orchidaceae } \\ \text { Habitus } & \text { :epifit } \\ \text { Sumber } & \text { :TNGR } \\ \text { Pohon penopang } & \text { :jabon }\end{array}$

Anggrek dalam genus ini adalah tanaman epifit dengan akar tebal,relatif tebal batang berserat dan banyak,besar,daun kasar dan di susun dalam dua peringkat anggrek ini mempunyai bunga ungu kemerahan.

\section{Psychopsis papilio}

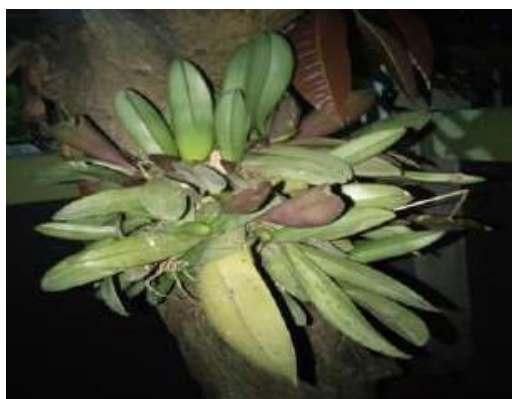

Gambar 6. Psychopsis papilio 


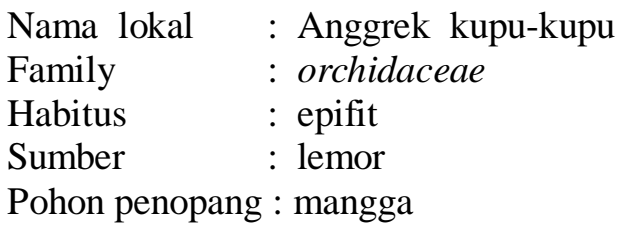

Anggrek ini adalah psychopsis papiliotapi juga ia punya julukan oncidium papilio ,butterfly orchid atau oncidium kupu-kupu anggrek ini banyak di sukai pencinta anggrek karena rajin berbunga bunganya besar umumnya , padatiap tangkai bunga hanya ada satu bunga yang mekar . tapi di belakangnya telah siap menanti kuncup baru yang akan mekar menggantikannya. Begitulah gambaran umum dari anggrek ini dan tak jarang kita melihat tanaman anggrek ini memiliki tangkai bunga yang panjang dan kokoh (kadang bercabang) dengan satu kuntum mekar di ujungnya tanaman anggrek ini juga toleran dengan kondisi teduh maupun setengah teduh.

\section{Phalaenopsis}

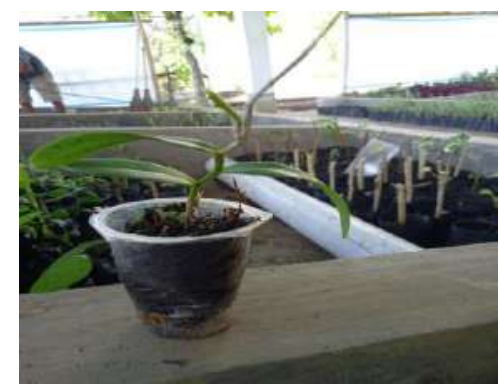

Gambar.7 Phalaenopsis

$\begin{array}{ll}\text { Nama lokal } & \text { : Anggrek Bulan } \\ \text { Family } & \text { : orchidaceae } \\ \text { Habitus } & \text { : epifit } \\ \text { Sumber } & \text { : lemor } \\ \text { Pohon penopang : } & \text { kamboja }\end{array}$

Anggrek bulan adalah salah satu spesies dari banyaknya anggrek jenis anggrek ini merupakan jenis anggrek yang kurangmenyukai sinar matahari dan pada umumnya anggrek bulan di simpan di dalam ruangan atau di luar ruangan yang sedikit terkena sinar matahari aroma harum dari anggrek bulan sangat khas ketika mekar sehingga tanaman hias bunga ini jadi pilihan bagi para pecintanya adapun bunga berbentuk serangga dan memiliki warna yang cerah dan perakaran yang kuat serbaguna menempel pada pohon inangnya.

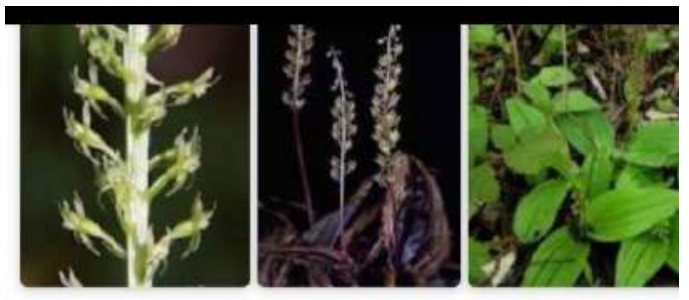

Gambar 8. Malaxis sp

Nama lokal : Anggrek mulut ader

Family : orchidaceae

Habitus : teresterial

Sumber : sembalun TNGR

Anggrek terestrial ini anggrek yan sebagian ditemukan di daerah trofis dan mempunyai ciri khas yang halus dan lembut pada daun nya dan teksturnya serta perakarannya yang kuat dan tajam.

\section{Eria javanica}

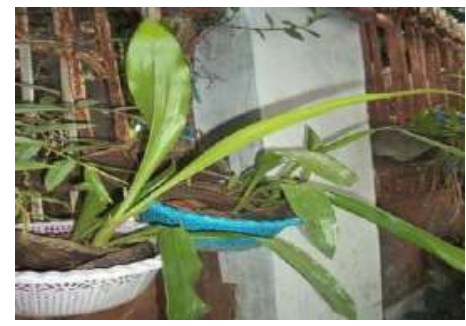

Gambar. 9 Eria javanica

$\begin{array}{ll}\text { Nama lokal } & : \text { Anggrek kenanga } \\ \text { Family } & : \text { orchidaceae } \\ \text { Habitus } & : \text { epipit } \\ \text { Sumber } & : \text { pusuk barat Lombok Barat } \\ \text { Pohon penopang } & \text { : pohon rambutan }\end{array}$

Anggrek ini merupakan anggrek liar yang keberadaanya mulai terkikis anggrekini sangatpotensial untuk dikembang biakan dan menjadisilangan anggrek ini termasuk sangat minim, secara rinci anggrek ini berbatang simpodial (tidak memiliki batang utama) yang sangat pendek dan tertutup oleh pangkal pangkal daun. Daunnya sendiri berukuran panjang hingga $50 \mathrm{~cm}$ dengan lebar sekitar 10 $\mathrm{cm}$ bunganya berwarna kuning ,ada juga yang putih bergaris merah sementara itu, musim berbunganya antara november -desember labbelumnya bergaris garis ungu dan menjadi ciri khas dari anggrek ini.

\section{Spathoglottis zurea}

\section{Malaxis $s p$}




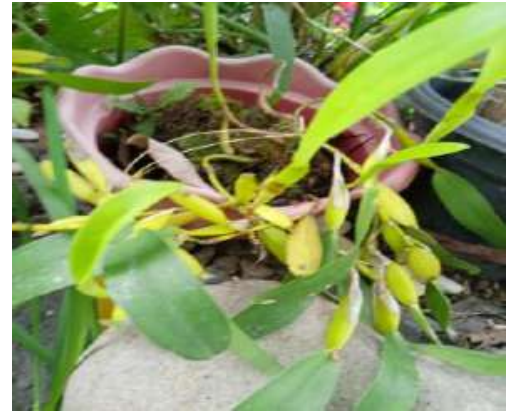

Gambar. 10 Spathoglottis zurea

$\begin{array}{ll}\text { Nama lokal } & : \text { Anggrek sendok } \\ \text { Family } & \text { : orchidaceae } \\ \text { Habitus } & \text { : epipit } \\ \text { Sumber } & \text { : NTB } \\ \text { Pohon penopang } & \text { kamboja }\end{array}$

Anggrek ini merupakan anggrek paling cantik di dunia dan memiliki keindahan bunganya yang kuning kecerahan dan sedikit bercorak putih dan merah anggrek sendok memiliki bunga yang bentuknya mirip sebuah bintang. Dimana iya memili kelopakbunga yang besar dan cukup lebar dan perakarannya yang cukup kuat tajam.

\section{Grammatophyllum speciosum}

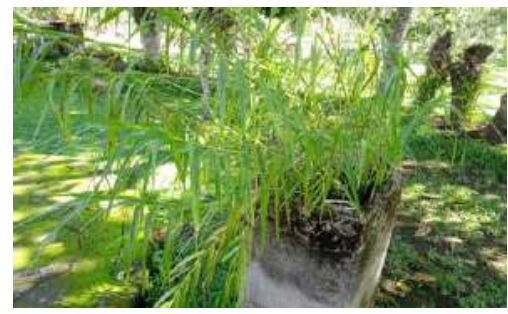

Gambar 11. Grammatophyllum speciosum

$\begin{array}{ll}\text { Nama lokal } & \text { : Anggrek tebu } \\ \text { Family } & \text { : orchidaceae } \\ \text { Habitus } & \text { : epipit } \\ \text { Sumber } & \text { : lemor } \\ \text { Pohon penopang } & \text { kamboja }\end{array}$

Anggrek ini merupakan anggrek yang paling besar dan berat di antara lainnya anggrek tebu dapat mencapai berat sampai satu ton kalau sudah dewasa dan mempunyai panjang malai hingga 3 meter dengan dia meter malai sekitar $1,5-2 \mathrm{~cm}$. Anggrek tebu sering juga di sebut anggrek macan keunikan anggrek ini membuat anggrek tebu dilindungi di indonesia.

\section{Vanda limbata (orchidaceae)}

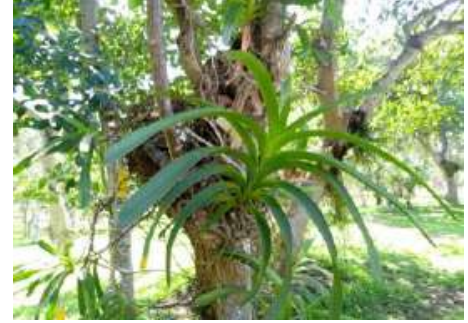

Gambar 12. Vanda limbata

Nama tanaman : vanda limbata Blume

family :orchidaceae

Habitus : Epipit

Pohon penopang : pohon rambutan

Sumber : Hutan lindung sambelia

Adapun Daunnya mempunyai jarak yang rapat, kurang lebih $1 \mathrm{~cm}$. Ukuran daunnya pendek dan lebar. Pinggir daunnya mempunyai warna yang lebih hijau. Akarnya Panjang dan selalu muncul/tumbuh pada bawah daun paling akhir. Ujung akarnya juga memiliki warna cokelat keunguan.

\section{Bulbophyllum carunculatum}

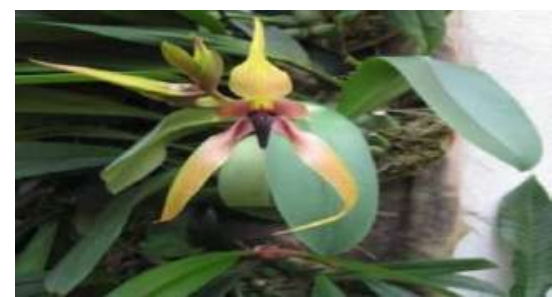

Gambar. 13 Bulbophyllum carunculatum

Nama tanaman :Bulbophyllum

family :orchidaceae

Habitus : Epipit

Pohon penopang : pohon rambutan

Sumber : Hutan lindung sambelia

Anggrek Bulbophyllum adalah Anggrek yang berhabitat epipit anngrek ini ditemukan diberagam habitat disebagian besar bagian dunia termasuk indonesia,afrika Anggrek dalam genus ini memiliki akar mirip benang atau berserat yang merayap dipermukaan pohon atau batu an juga menggantung dari cabang batang dibagi menjadi rimpang,pseudobulb fitur yang membedakan genus ini dari dendrobium. Biasanya hanya ada satu daun dibagian atas pseudobulb dan dari satu ke banyak bunga disusun sepanjang batang berbunga yang tidak bercabang yang muncul dari pseudobulb.

\section{Pteroceras pallidum}




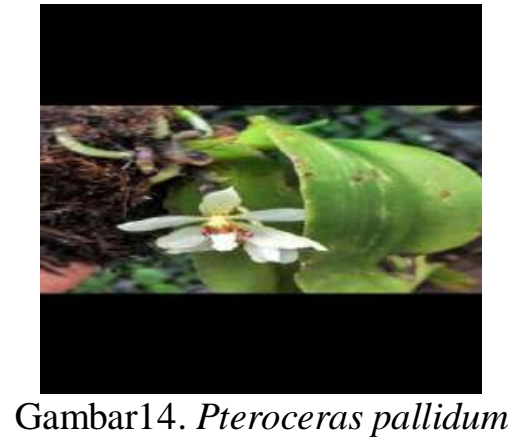

Nama tanaman : Bulbophyllum

family :orchidaceae

Habitus : Epipit

Pohon penopang : pohon jambu

Sumber : Hutan pusuk sembalun

Anggrek ini merupakan spesies yang tersebar di daerah negara Asia tenggara termasuk Anggrek monopodial Anggrek ini mekar hanya sehari anggrek ini memiliki rimpang bawah yang pada umumnya besar, dibawah tanah berdaging dan mengindikasikan kebiasaan pertumbuhan monopodial.

\section{Thelasis carinata}

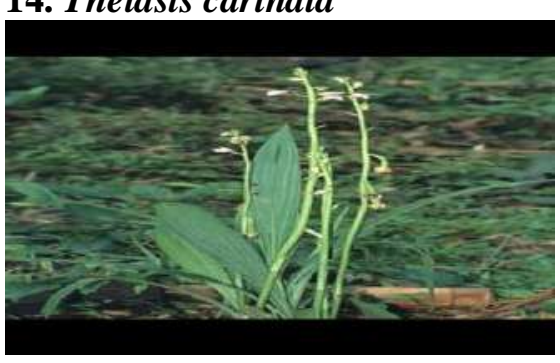

Gambar 15. Thelasis carinata

Nama tanaman : Thelasis carinata

family : orchidaceae

Habitus : Epipit

Pohon penopang : pohon jambu

Sumber : Hutan Sembalun Lombok

Timur

Anggrek ini umumnya dikenal sebagai anggrek lalat berbentuk segitiga termasuk habitat epipit pembentuk rumpun atau yang terdiri dari dua dan enam batang yang rata dan masing masing memiliki hingga enam daun yang memiliki permukaan bawah yang bergerigi.hingga lima belas bunga hijau dan putih disusun pada batang berbunga yang tipis namun kaku.Anggrek banyak ditemukan di thailand hingga pasifik barat daya.

\section{Acampe}

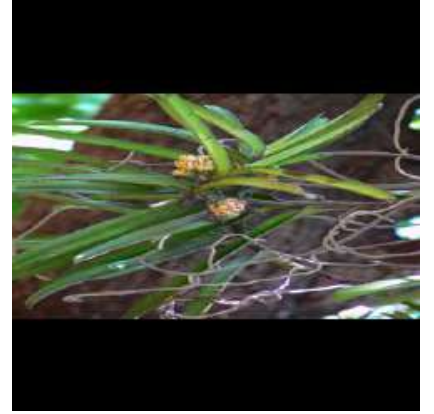

Gambar 16 Acampe

Nama tanaman : Acampe

family :orchidaceae

Habitus : Epipit

Pohon penopang : pohon kamboja

Anggrek ini merupakan anggrek yang merambat yang berukuran sedang yang tumbuh lambat yang membentuk massa vegetatif yang sangat besar di alam. Anggrek ini terkenal karena daunnya yang tebal,kasar, dan halus juga menghasilkan bunga kuning ukuran kecil hingga sedang, dilarang dengan garis-garis oranye atau merah, dalam bentuk sedikit sampai banyak bunga racemose.sepal dan kelopak yang rapuh terlihat sama labellum atau bibir berbentuk telinga,berpohon, berwarna,putih didasarnya kolom berdaging pendek dan memiliki pollonia berlilin.

\section{Phaius Tankervilleae}

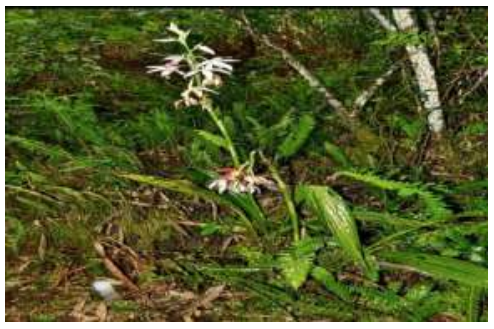

Gambar 17. Phaius Tankervilleae

Nama tanaman : Phaius Tankervilleae

family :orchidaceae

Habitus : teresterial

Pohon penopang : pohon kamboja

Anggrek ini tumbuh sebagian besar di hutan raya atau padang rumput dan di temukan di wilayah papua bahkan ada juga di australia Anggrek ini terbilang cukup langka, habitat aslinya,ia ada di bagian lain dunia sebagai spesies yang di naturalisasi.

Anggrek ini terancam punah di indonesia ini terancam oleh menginjak-injak persediaan, dan 
oleh pengumpulan ilegal,gulma,drainase habitatnya.

\section{Crepidium Koordersii}

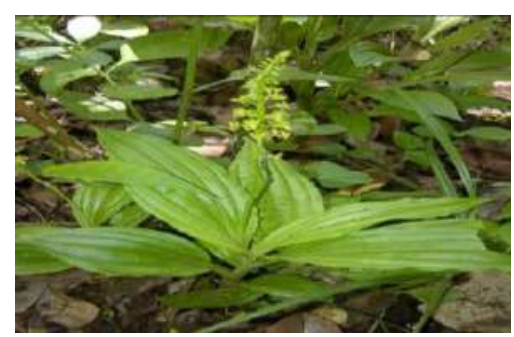

Gambar 18. Crepidium Koordersii

$\begin{array}{ll}\text { Nama tanaman } & : \text { Crepidium Koordesii } \\ \text { family } & \text { :Orchidaceae } \\ \text { Habitus } & : \text { Teresterial } \\ \text { Pohon penopang } & \text { : pohon kamboja } \\ \text { Sumber } & \text { : HL. Sebau }\end{array}$

Anggrek ini umumnya dikenal sebagai Anggrek cina yang di bisa memacu genus dari sekitar tiga ratus spesies anggrek Dalam Keluarga Orchidaceae.tanaman dalam genus ini hijau sepanjang masa,sebagian besar tanaman terestrial dengan batang pendek tergeletak di tanah, dua atau lebih relatif besar, daun berlipit dan bunga-bunga kecil,non-resupinate dengan menyebarkan sepal dan kelopak bunga.genus ini diistribusikan secara luas diaerah tropis.

\section{Arundinagraminifolia}

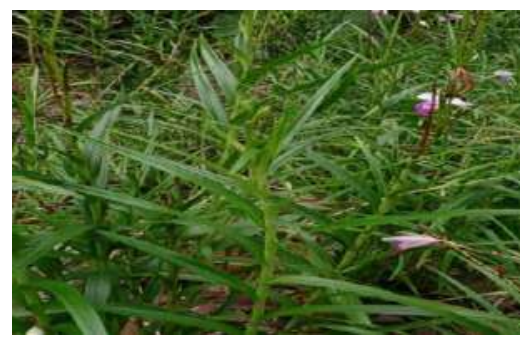

Gambar 19. Arundinagraminifolia

Nama tanaman : Arundinagraminifolia

family :Orchidaceae

Habitus : Teresterial

Pohon penopang : pohon jambu batu

Sumber : Wanasaba

Arundinagraminifolia Adalah Anggrek Terestrial, Abadi Dengan Batang Reedy, Membentuk Rumpun Besar Yang Tumbuh Hingga Ketinggian Antara 70cm Dan 2m Daun Linier Anyaman Berbentuk Lanceolate, Dengan Panjang 9 Hingga $19 \mathrm{~cm}$ dan Lebar 0,8 Hingga
1,5 Cm Apeksnya Tajam. Ada Ketentuan Selubung Amplexicual. Kelompok Bunga Terminal Yang Agakterbuka Paling Banyak Sepuluh Mereka mekar BerturutTurut.Panjangnya7 Sampai16cm. Bunga-Bunga Ini Berdiameter 5-8cm, Berwarna Ungu Kemerahan Dan Cakram Putih Dengan Bibir Ungu.

Berdasarkan Jumlah data koleksi Anggrek yang ada di kebun raya lemor Desa Suela kecamatan Suela terdapat 22 jenis anggrek yang teridentifikasi habitat terrestrial dari jumlah 60 jenis Anggrek yang di dominasi Anggrek habitat epipit yang ada di kebun raya.Anggrek terestrial adalah anggrek yang tumbuh di permukaan tanah dan membutuhkan cahaya matahari langsung.meski tumbuh di permukaan tanah, tetapi anngrek tersebut jangan di tanam langsung di tanah. Anggrek ini masih membutuhkan media lain seperti serutan kayu, sabut kelapa, atau sejenisnya. Media itu masih di campur lagi dengan kompos bambu atau sejenisnya dan pupuk kandang yang sudah matang. Anggrek terrestrial umumnya di tanam dengan system bedengan, walaupun dapat pula di tanam dalam wadah pot tanah atau sejenisnya.(Anynomous 2019)

Pohon penopang merupakan tonggak untuk menahan sebuah anggrek yang menumpang diatas suatu pohon untuk membantu proses tumbuh kembang nya suatu anggrek yang dimana anggrek tersebut tidak merugikan pohon inangnya ada enam jenis pohon penopang anggrek yang di temukan dilokasi atau blok koleksi anggrek dikebun raya lemor, yaitu Mangga,jambu batu,rambutan,jabon ,kamboja,jeruk

\section{KESIMPULAN}

Berdasarkan hasil identifikasi dalam penelitian ini, dapat di simpulkan sebagai berikut.

1.Terdapat 2 jenis Anggrek yang merupakan endemik Lombok yaitu Vanda lombokensis dan Dendrobium rinjaninsis. Sedangkan yang teridentifikasi hanya vanda lombokensis.ciri khas bunga anggrek endemik lombok ini terdapat pada warna dasar kelopak bunga, yakni putih dan kuning serta totolnya yang khas dengan warna cokelat dan merah..dan terdapat pula anggrek bukan endemik Lombok yang teridentifikasi sebanyak 58 jenis

2.jenis Anggrek berdasarkan Habitatnya di temukan yaitu epipit, terrestrial jumlah jenis 
epipit sendiri sebanyak 38 jenis dan jumlah terrestrial 22 jenis.

3. Di temukan ada 6 penopang untuk anngrek yaitu Mangga,jambu batu,rambutan,jabon ,kamboja,jeruk.

\section{SARAN}

Diperlukan kesadaran masyarakat untuk ikut menjaga populasi vanda lombokensis di TNGR. Perlunya fasilitas yang memadai dari pemerintah agar anggrek ini dapat di budidayakan dan di perkenalkan kepada masyarakat luas.

\section{DAFTAR PUSTAKA}

Albarkhati K. 2016. Kondisi Populasi Penyebaran Anggrek Eria spp. di Resort Balik Bukit Taman Bukit Barisan Selatan. Skripsi: Universitas Lampung. Lampung. $55 \mathrm{hlm}$.

Ambarwati, 2019. Identifikasi Jenis Anggrek Pada Bol Koleksi Tumbuhan dan/Atau Satwa Tanaman Hutan Raya Wan Abdul Rachman. Fakultas Pertanian Universitas Bandar lampung.

Anynomous 2019, Data Koleksi Anggrek Kebun Raya Lemor, Proyeksi BPS Kab.Lombok Timur.

Anonymous, 2019. Anggrek Merupakan Salah Satu Jenis Tanaman Nasional Gunung Rinjani, Taman Nasional Gunung Rinjani. https/face book.com Posts. Taman Nasional Gunung Rinjani ( diakses tgl 20 Agustus 2020)

Heriswanto, K., 2009. Berkibarlah Anggrek Indonesia. BBI Dins Kelautan dan Pertanian Propinsi DKI Jakarta: Jakarta

Kartohadiprodjo, 2009. Asyiknya Memelihara Anggrek. Jakarta. PT. Gramedia Pusat Utama

Latief, S.M,. 1960., Bunga Anggrek Permata Belantara Indonesia. PT Sumur, Bandung.

Musa, F.F., Syamsuardi, dan Arbain, A. 2013. Keanekaragaman jenis orchidaceae di kawasan hutan lindung gunung talang sumatera barat. Jurnal Biologi Universitas Andalas. 2(2):153-160. 